\section{Is it a telecommunications issue or is it a copyright issue?}

Libraries are participating in a filing to the Federal Communications Commission (FCC) on the impact of a proposed FCC rule mandating a "broadcast flag" copy protection for digital television. The broadcast flag and other copy protection mechanisms present a serious potential adverse impact on libraries and educational institutions by preventing them and their patrons from exercising fair use and other rights under copyright law.

The FCC's rulemaking is designed to facilitate the transition to digital television (DTV) and will explore whether the FCC can and should mandate the use of a copy protection mechanism for digital broadcast television, and what impact such a regulation would have on consumers.

The written comments on a "broadcast flag" copy protection were required to be filed by December 6 , with reply comments due January 17 , 2003. The five major national library associations (ALA, American Association of Law Libraries, Association of Research Libraries, Medical Library Association, and Special Libraries Association) have filed their comments.

The impetus for the FCC's proceeding is a belief by Congress and the FCC that the current lack of digital broadcast copy protection, which would prevent the unauthorized copying and redistribution of digital media, keeps content providers from allowing the digital broad- cast of high-quality programming. Without such programming, the argument goes, consumers may be reluctant to buy DTV receivers and equipment, thereby delaying the DTV transition.

Private industry negotiations have reached some consensus on a technical "broadcast flag" standard (ATSC Standard A65/A), which would limit the copying of some of the programming aired by broadcast television stations. However, there is no universal agreement on the use and implementation of the flag. There also is no industry agreement on how to enforce digital broadcast copy protection. The rulemaking seeks comment on the jurisdictional basis for FCC action in this area and whether the FCC should intercede in this matter. (Note that Congress also is considering action on the broadcast flag and may end up preempting the FCC in mandating such copy protection.)

Go to our Web page at http://www.ala. org/washoff/digrights.html/ for background information and to see a copy of our joint comments.

All other legislative issues remain dormant until the new Congress is sworn in on January 6,2003 . There will be major initiatives of concern to academic librarians especially on copyright and electronic surveillance and privacy issues. Watch for more information from ACRL as we gear up for the new Congress.

Miriam Nisbet is ALA Legislative Counsel, e-mail: mnisbet@alawash.org

\title{
Meet the ACRL Board
}

Members of the ACRL Board of Directors will be manning the association's exhibit booth during the ALA Midwinter Meeting in Philadelphia. Don't miss this opportunity to learn more about the benefits of ACRL membership or catch up with your colleagues.

Board members will be available at the booth to give in-depth answers to your questions and provide guidance and connections.
For a list of ACRL Board members, visit http://www ala.org/acrl/boardhp. html.

We plan to have Board members available Friday, January 24 through Monday, January 27. A finalized schedule will be available on the ACRL Web site beginning January 10.

The ACRL booth is number 1032 in the exhibits hall. See you there! 


\section{"Then we need to change that social policy."}

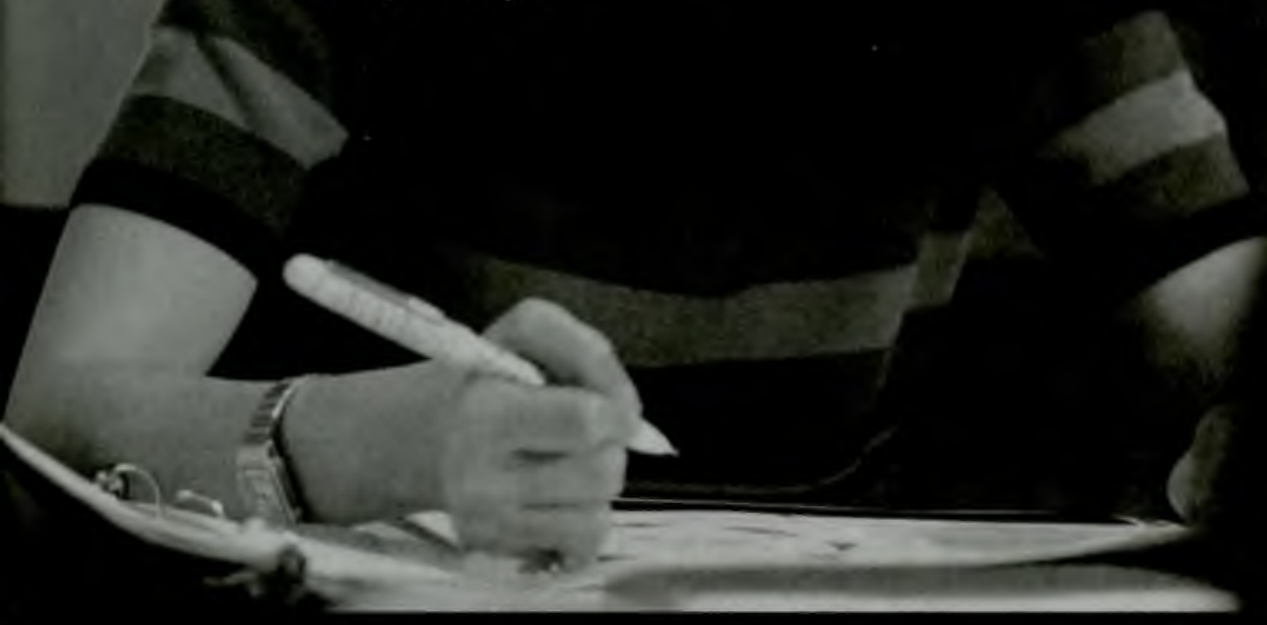

She needs your help to find the best resources on public affairs and social policy research. There's no better place than PAIS International. Books, journals, gov docs, web sites-the PAIS International in Print index and online database provide fast paths to knowledge.

Which is just what she needs to start creating public policies of her own. Learn how you can help her at www.pais.org. 